\title{
Liberdade e denúncia social no texto poético de autoria feminina: análise da obra o nome do amanhã, de Marina Colasanti
}

\author{
Freedom and social report in the poetic text of female authory: análisis of the work o nome do amanhã, by \\ Marina Colasanti
}

\section{Eliane Aparecida Galvão Ribeiro Ferreira}

Universidade Estadual Paulista “Júlio de Mesquita Filho" - UNESP - São Paulo - Brasil

\author{
Ricardo Magalhães Bulhões \\ Universidade Federal de Mato Grosso do Sul - UFMS - Três Lagoas - Brasil
}

\begin{abstract}
Resumo: Este texto, a partir do aporte teórico da Estética da Recepção e do Efeito (JAUSS, 1994; ISER, 1996 e 1999), apresenta análises de poemas que compõem a coletânea $O$ nome da manhã, de Marina Colasanti (2012). Justifica-se a escolha dessa obra, pois seus poemas são atraentes para o jovem leitor, possuem temas universais e contemporâneos, bem como potencialidades que despertam seu senso crítico e desautomatizam suas concepções sobre usos da língua, distinções estanques entre gêneros textuais e literatura de autoria feminina. Pelas análises, detectou-se que seu eu lírico, como exercício de resistência e subversão à ordem capitalista, captura em seu discurso cada instante como único, retirando-o da velocidade que define a vida hodierna, que a tudo atribui valor e/ou dilui. Os poemas de Colasanti (2012), pautados por vazios e potências de negação, suscitam reflexão crítica do leitor, por meio da revisão de hipóteses. Para tanto, evocam dados familiares com a finalidade de relativizá-los e/ou negá-los, ajustando o processo interativo na leitura. Por meio desse processo, eles suscitam do leitor que situe a si mesmo em relação ao texto, bem como atualize e modifique seu ponto de vista de uma perspectiva de apresentação para outra. Nesse processo, instaura-se a linguagem poética dotada de valor estético e a comunicabilidade que convoca o olhar de descoberta, o qual assegura o prazer intelectual na leitura (ISER, 1999.
\end{abstract}

Palavras-chave: Estética da Recepção e do Efeito. Literatura juvenil de autoria feminina. Leitor implícito. Texto poético.

\begin{abstract}
This text, based on the theoretical contribution of the Aesthetics of Reception and Effect (JAUSS, 1994; ISER, 1996 and 1999), presents analyzes of poems that compose the collection O nome da manhã, by Marina Colasanti (2012). The choice of this work is justified because its poems are attractive to the young reader, they have universal and contemporary themes, as well as potentialities that awaken their critical sense and de-automate their conceptions about language uses, watertight distinctions between textual genres and authored literature female. Through the analysis, it was found that his lyrical self, as an exercise of resistance and subversion to the capitalist order, captures uniqueness in his discourse each moment, removing it from the speed that defines today's life, which attributes value and/or dilutes everything. Colasanti's poems (2012), marked by voids and powers of negation, provoke critical reflection in the reader, through the revision of hypotheses. For that, they evoke familiar data in order to relativize and/or deny them, adjusting the interactive process in reading. Through this process, they ask the reader to situate him or herself in relation to the text, as well as to update and modify his point of view from one presentation perspective to another. In this process, the poetic language endowed with aesthetic value is established and the
\end{abstract}


communicability calls for a look of discovery, which ensures intellectual pleasure in reading (ISER, 1999).

Keywords: Reception Theory. Young-adult women-authored literature. Implicit reader. Poetic text.

\section{Introdução}

Objetiva-se, neste texto, apresentar uma análise de poemas que compõem a coletânea $O$ nome da manhã, de Marina Colasanti (2012), refletindo sobre como a autora lida em sua enunciação com a condição de duplicidade de seu discurso feminino, que se apresenta, conforme Elaine Showalter, constituído por duas vozes, as quais personificam "as heranças social, literária e cultural, tanto do silenciado quanto do dominante" (1994, p.50). Constrói-se a hipótese de que seus poemas, pelo viés libertário e crítico, se voltam para o leitor implícito, relativizando certezas e problematizando determinações sociais, rompendo, assim, com conceitos prévios e ampliando seu horizonte de expectativa. Acredita-se que esses poemas, pelo valor estético e por contemplarem temas contemporâneos, e universais, podem ser cativantes para o jovem em formação, bem como emancipatórios.

Pela brevidade deste artigo, opta-se pela análise de alguns poemas da coletânea (2012), por meio da qual se pretende investigar a expressividade feminina que se apresenta nesses textos enquanto provocação para que o jovem leitor lhes atribua sentidos. Nesse processo, pela leitura, esse leitor significa não apenas os poemas, mas a si mesmo e ao seu entorno. Na dialogia com esse leitor, Colasanti (2012), pela maestria no trato com a palavra, utiliza em seus textos formas singulares de exercer e transgredir a condição de silenciamento da voz feminina. Interessa, então, analisar que formas são essas. Constrói-se a hipótese de que sua obra (2012), por dialogar com a tradição literária, apresentar discurso crítico e estabelecer comunicabilidade com seu leitor implícito (ISER, 1996 e 1999), requer produtividade na leitura, em especial, memória de leituras anteriores e dados culturais, por isso pode auxiliar na formação do leitor estético, sobretudo na ampliação de seu horizonte de expectativas.

Para a consecução desse objetivo, busca-se, a partir do aporte teórico da Estética da Recepção e do Efeito (JAUSS, 1994; ISER, 1996 e 1999), refletir sobre quais elementos em seus poemas podem ser atraentes para o jovem, despertar seu senso crítico sobre as relações humanas em sociedade e desautomatizar suas concepções sobre usos da língua, distinções estanques entre gêneros textuais e literatura de autoria feminina. A opção por esse aporte teórico deve-se ao fato de a obra juvenil procurar claramente interação com seu público visado. Por sua vez, justifica-se a reflexão sobre a produção de autoria feminina, pois é definida muitas vezes, segundo Vera Lúcia Dietzel (2002), de forma preconceituosa, como apenas de valor documental e/ou panfletário, associada a um marxismo vulgar. Além disso, conforme João Luís Ceccantini (2004), faltam estudos que considerem as especificidades de obras juvenis. Em especial, os que se debrucem, de acordo com Teresa de Lauretis (1994), sobre a escrita de autoria feminina enquanto outro lugar nos discursos hegemônicos e em suas representações sociais.

\section{Uma produção voltada à denúncia}

Marina Colasanti, atualmente, é um dos nomes mais conceituados na produção literária de autoria feminina. Sua produção é vasta, possui mais de 50 títulos em gêneros textuais diversos, publicados tanto no Brasil quanto no exterior, o que justifica sua indicação, pela FNLIJ - Fundação Nacional do Livro Infantil e Juvenil, ao Prêmio Hans Christian Andersen em 2020 (NOTATERAPIA, 2020). A escritora, nascida na cidade de Asmara, Eritreia, antiga Etiópia, a 26 de setembro de 1937, possui formação em Artes, também é pintora, gravurista, publicitária, ilustradora, jornalista 
e tradutora. Em meio à guerra, teve uma infância nômade, transitou, aos quatro anos de idade, da cidade de Trípoli, capital da Líbia, para a Itália, onde permaneceu até os onze. Em 1948, sua família radicou-se no Rio de Janeiro (COLASANTI, 2010 e 2012; MARINACOLASANTI.COM, 2020).

Colasanti escreve obras literárias para diferentes públicos, além de ensaios sobre temas pertencentes ao universo literário, feminino, social e político contemporâneo. Pelos inúmeros prêmios nacionais e internacionais recebidos, bem como pelo valor estético, sua obra é reconhecida pela crítica especializada e tem sido objeto de estudos acadêmicos. Por sua vez, a coletânea $O$ nome da manhã (2012) recebeu o Prêmio "Altamente Recomendável" na categoria Poesia, concedido pela FNLIJ, em 2013 (MARINACOLASANTI.COM, 2020). Nessa obra (2012), Colasanti, por meio de uma elaboração linguístico/poética precisa, revitaliza, em vários poemas, a função de combate da qual se mune o poeta para falar da sua rua, do seu bairro, do seu país. Existe na sua poesia um canto de resistência, uma atmosfera inquietante de repercussão imprevisível. Aliás, a produção literária de Colasanti define-se pela liberdade criativa e ruptura com delimitações entre gêneros textuais, a qual a filia à pósmodernidade. Desse modo, seus textos em prosa apresentam características líricas que os configuram como poéticos, e seus textos poéticos possuem elementos que estruturam uma fabulação. Prevalece nesses textos uma literatura engajada, marcada pela denúncia de formas de opressão e pela resistência a consensos sobre o papel da mulher na sociedade.

Em O Nome da Manhã (2003), a escritora projeta um leitor astuto, com capacidade de dedução das raízes sociais. Uma das características da obra é a simbiose entre o fazer poético e o cotidiano, o ficcional e a realidade que se fundem o tempo todo. Nota-se, assim, que o rumor das palavras conecta-se com o das ruas, estabelecendo uma aproximação íntima entre poeta e leitor. Por meio de seus poemas narrativos concisos e densos, Colasanti estabelece analogias que permitem reconhecer o processo de realização da obra, a partir da afinidade de temas e procedimentos formais ligados à tradição, mas também à contemporaneidade. Esses recursos impulsionam o leitor juvenil a se deparar com situações tanto cotidianas, quanto inusitadas, com atmosferas de violência experenciadas por sujeitos ou seres que pertencem ao seu meio social. Nesse sentido, o processo criativo aproxima-se de tipos socialmente "descartados", figuras que perambulam nas cidades, maltratadas e imersas na rudeza do dia a dia, gente que ninguém vê, figuras invisíveis recriadas na obra, na experiência artística, temas afins e recursos formais diretamente ligados a poetas como Drummond, João Cabral, Mário Quintana, Ferreira Gullar, entre tantos outros modernistas, concretistas e contemporâneos.

Dessa forma, Colasanti ativa em sua produção poética a função social, pois inquieta o leitor, convida-o a repensar o mundo e se autoconhecer. Para tanto, rompe com os modos usuais de percepção e avaliação, visando a ampliar seus horizontes de expectativa (JAUSS, 1994; ISER, 1996 e 1999). Justamente, com a intenção de causar estranhamento e propor reflexão, a escritora estrutura sua coletânea O nome da manhã (2012), composta por 49 poemas, em seis partes separadas por folhas divisórias da mesma cor de seus títulos no sumário (p.4-5): 1. "Mais um dia começa" (p.7-14), em vermelho; 2. "Estranheza com beleza" (p.15-23), em verde-claro; 3. "Os dentes e a fome" (p.25-31), em verde-abacate; 4 . "O outro e o mesmo" (p.33-40), em mostarda; 5. "Inventar a própria história" (p.41-48), em azul-claro; e 6. "O futuro é sempre adiante" (p.49-57), em rosa. Pelo emprego das cores e das ilustrações, o projeto gráfico resulta atraente para o olhar do jovem leitor. Pelos títulos de cada parte, bem como pelos temas explorados em seus poemas, percebe-se que funcionam como alegoria das horas que dividem o dia, configurando-se, de forma cronológica, como: 1. primeira parte da manhã; 2. segunda parte, que antecede o almoço; 3. meio-dia; 4. primeira parte da tarde; 5 . segunda parte da tarde; 6. noite e madrugada. Como alguns de seus poemas tratam da existência nessas horas, pode-se interpretá-los como alegorias das fases da vida ou também de (re)nascimentos do ser humano a cada novo dia. 
As mesmas cores que aparecem nos títulos do sumário e nas divisórias permeiam o projeto gráfico. Assim, as orelhas em azul-claro, semelhantes à cor do título "Inventar a própria história", evocam a própria criação da escritora que margeia seu livro, seu construto. A capa, em vermelho, no mesmo tom do título "Mais um dia começa", indica que os poemas tratam da temporalidade. O tombo, em verde-claro, como o título "Estranheza com beleza", conota a necessidade de acionar a reflexão, promovida pelo estranhamento, durante a fruição estética. E a quarta capa em mostarda, semelhante ao título "O outro e o mesmo", sugere que a leitura promove uma revisão sobre o conhecido. Nota-se, então, um planejamento visual que estabelece comunicabilidade com o leitor, desalojando-o de qualquer atitude filiada somente à contemplação.

Pela leitura dos poemas e do projeto gráfico, avulta a concepção de que é papel da Arte anunciar o "novo", embora este seja bem conhecido. Esse novo olhar extrapola o corriqueiro, por meio da fruição do texto poético, pautado pela crítica e denúncia, as quais podem promover desejos de mudança social. Seu projeto gráfico, pelas ilustrações coloridas em todas as páginas, indica que seu público é o jovem. Conforme Rui de Oliveira (2008), a ilustração tem por finalidade criar a memória afetiva do jovem e propiciar a desautomatização de seu olhar em relação à imagem. Justamente, o projeto gráfico da obra de Colasanti (2012) revela uma intenção de leitura a partir da exploração de cores e do diálogo entre texto verbal e imagético, pois o sentido emerge da relação de colaboração entre ambos (LINDEN, 2011), projetando um leitor implícito (ISER, 1996 e 1999) capaz de perceber esse jogo.

Suas ilustrações caracterizam-se pelo movimento, sendo, pois, narrativas, conforme Luís Camargo (1998). Elas se assemelham aos poemas com que dialogam, pois estes também se configuram pela captura de um instante ora vazado pela narratividade, ora pela subjetividade. As ilustrações são metonímicas, por isso conferem relevo a um ou dois elementos descritos no poema. Um exemplo pode ser notado no texto a seguir, retirado da primeira parte do livro, intitulada "Mais um dia começa" (2012, p.914):

Insone
Passei a noite em claro,
nem o galo cantou
nem a coruja
e o dia chegou avaro
sobre a cidade suja.
(2012, p.13)

No poema, a oposição entre os vocábulos "noite" e "dia" é latente, sugerindo um conflito entre as categorias de tempo, espaço e sujeitos, aos quais foi negado o direito à voz - "nem o galo cantou/nem a coruja" (2012, p.13 - grifos nossos). Desse modo, esses animais não cantam e essa constatação é expressa tanto pela potência de negação (ISER, 1999) - marcada pelo emprego do advérbio de negação "nem" -, quanto pela elipse do verbo "cantar". Esses recursos utilizados pela poeta instauram vazios no poema e suscitam interação (produtividade), pois sem cancelar o universo conhecido pelo jovem leitor, negam o que expressam, e omitem um vocábulo que ele precisa resgatar na leitura. O jogo semântico instaurado pelo discurso do eu lírico, feito por lacunas, afirmações e negações, permite que o leitor projete de forma imaginária a cena e situação apresentadas, aproximando-as e afastando-as de si mesmo, e de sua realidade. Desse modo, ele amplia seu horizonte de expectativa, por meio de uma revisão de seus conceitos prévios.

As performances do "galo" e da "coruja", pautadas pela negação, advém do não reconhecimento desses animais do espaço e do tempo, pois se sentem estranhos, excluídos do cenário urbano. Justamente, a ausência de reconhecimento desses animais advém da dificuldade de distinguirem entre "claro" e "escuro", assim como o eu lírico. Este passa a noite "em claro", sofre com a insônia, por sua vez, quando chega o dia, suas expectativas não se realizam, pois falta luz, nitidez, por isto "[...] o dia chegou avaro" (2012, p.13). Vale destacar a aproximação, pelo plano sonoro, na rima externa entre "claro" e "avaro". Pode-se deduzir que a urbanização voraz, com suas lâmpadas, ilumina a noite e, com a verticalização de estruturas de concreto, contamina de 
sombras o dia. Esse cenário é compatível com a visão de Mário Quintana em seu texto "Poema da Circunstância": "Onde estão os meus verdes?/Os meus azuis?/O arranha-céu comeu! [...]/Para que lhes serviu beberem tanta luz?!" (ARMAZÉM DE TEXTO, 2020), referindo-se aos edifícios que também devoram o verde. A ilustração de uma coruja cinza, empoleirada sobre um tronco de árvore ressequido e quebrado ao meio, que dialoga esse poema (2012, p.13), confere ênfase a essa dedução, além da rima externa entre os vocábulos "coruja" e "suja". O olhar distante dessa ave, capturado no momento em que virou sua cabeça à esquerda, conota melancolia, provocada pelo sentimento de inadequação. O tom de denúncia social de realidades opressivas acentua-se justamente na confluência entre essa ilustração e o texto verbal.

Assim, os adjetivos "sujo", associado à cidade, e "avaro", ao dia, encontram correspondência no cenário urbano desolador, bem como nos traços em preto que ultrapassam a ilustração da coruja, criando efeito de ruído, pois impedem que ela se apresente de forma mais nítida. A avareza do meio urbano, por sua vez, evoca a destruição da natureza em prol do capital, promovendo a poluição, a sujeira na cidade. Essa atmosfera do poema, em diálogo com o título dessa primeira parte da coletânea, indica que o cenário urbano não será alterado, mesmo que "mais um dia" comece. Ademais, pela rima interna nos versos: "nem o galo cantou/[...]/e o dia chegou avaro" (2012, p.13 grifos nossos), nota-se que o nascer de um novo dia será inevitável, esteja o galo cantando - anunciando o seu surgimento - ou não.

Como se pode notar, Colasanti (2012) imprime o poético na ilustração e a narratividade no poema, subvertendo fronteiras textuais diversas e incorporando as inovações da produção contemporânea, cuja tônica recai, conforme Yves Stalloni, na "aspiração à liberdade" (2001, p.168). A escansão silábica também é um elemento que sustenta a visão da narratividade nos poemas, os quais se apresentam com alternâncias das sílabas poéticas e das rimas, sugerindo um tom prosaico, de fácil assimilação, aproximando os textos ao ato de narrar. Outro fator relevante nos poemas que os direciona ao narrativo é a presença de traços da oralidade, exercendo o movimento de associar o texto literário ao prosaico. Revela-se, assim, a consciência aguda da escritora em relação ao seu construto.

As ilustrações na obra (2012) remetem à aquarela e apresentam função estética (CAMARGO, 1998), pois destacam a configuração visual, com o objetivo de sensibilizar, por meio de sobreposições de cores e alternâncias de tons. Como elas não se situam na mesma posição nas páginas, aparecendo ora baixo, ora acima ou ao lado do poema com o qual dialogam, surpreendem o olhar habituado à previsibilidade. As linhas simples e bem marcadas na cor preta que as compõem, os discretos traços que as ultrapassam e a originalidade, evocam a técnica da gravura, embora perpassada na edição do livro pela tecnologia. A função narrativa das ilustrações estabelece homologia com os poemas, pautados pelo prosaico, pois constituem, em sua maioria, descrições de fatos ou acontecimentos. Apesar da narratividade, os poemas afastam-se dos textos clássicos e medievais, bem como dos produzidos no século XIX, pois não expressam feitos épicos, nem ensinamentos edificantes. São textos que relatam algum tipo de peripécia e se pautam pela brevidade, musicalidade e humor. Sua narratividade entrelaça-se com três linguagens: a poética, a narrativa e a pictórica. Apesar de esse entrelaçamento atribuir complexidade à leitura, sua riqueza recai nas novas possibilidades que oferece de exploração do imaginário e da sensibilidade do jovem leitor.

$\mathrm{Na}$ atualidade, as escolhas de Colasanti (2012), pela técnica milenar da gravura e de incorporação do prosaico nos poemas, aproximam seus textos e suas ilustrações da tradição. Todavia, como integrantes de uma obra contemporânea, seus textos verbais e imagéticos subvertem, pelo tratamento lúdico de viés crítico, pela eleição de temas mundanos e de linhas simples, o diálogo com a erudição. Desse modo, configura-se na obra, de forma original, o diálogo entre $o$ antigo e tradicional e 0 revolucionário, este atuando como alegoria do projeto estético da autora, a recusa da obviedade e da produção em série, pautadas pelo capital. Sua obra 
define-se pela dualidade e autoconsciência criadora, por isso resgata a tradição, reconhece suas contribuições, mas a subverte na ânsia de, pela liberdade, encontrar e exercer a própria voz.

Linda Hutcheon (1991) aponta que é característica fundamental da produção contemporânea essa autoconsciência em relação à maneira como um texto é construído. Colasanti em seu processo de criação também busca uma dicção autêntica, que pode ser notada na segunda parte do livro, intitulada "Estranheza com beleza" (2012, p.1523) e, igualmente, no poema a seguir:

\section{Penas em Ipanema}

O galo na calçada
não é transeunte
não é turista errante
meliante não é.
O galo na calçada
é fato inusitado
nesse bairro elegante.
Avança coroado
ciscando indiferente,
não canta,
silencioso vai dando
seu recado:
sou do morro
ali ao lado. (2012, p.23)

A aproximação desse poema, além do título da coletânea de Colasanti, dos poemas narrativos "Tecendo a manhã", de João Cabral (ESCRITAS.ORG, 2020), e "Galo Galo", de Ferreira Gullar (JORNAL DE POESIA, 2020), torna-se inevitável. Os pontos de contato efetivam-se, por meio da linguagem e, sobretudo, da eleição desse animal. Como em João Cabral e Gullar, o lirismo, na produção poética de viés narrativo de Colasanti, é direcionado mais pela inteligência do que pelo sentimentalismo.

No poema "Penas em Ipanema" (2012, p.23), de Colasanti, é curioso perceber que o galo - animal do meio rural - passeia na cidade grande. Justamente, por isto, o eu lírico sente necessidade de defini-lo, afastando-o das categorias que são atribuídas aos sujeitos do meio social em que vive. Para tanto, utilizase da potência de negação, do recurso à rima interna, à anáfora e ao quiasmo: "não é transeunte/não é turista errante/meliante não é“ (2012, p. 23 - grifos nossos). Por meio desses recursos estilísticos, o galo escapa das classificações dos grandes centros urbanos, em que se encontram: "transeuntes", "turistas errantes" e "miliantes". O emprego do quiasmo conota o desejo do eu lírico de impedir a alienação do jovem leitor, pela subversão da ordem usual dos versos anteriores. $\mathrm{Na}$ aproximação sonora entre "errante" e "miliante“, suscita desse leitor reflexão sobre as razões que motivam a criminalidade, sendo, entre elas, a ausência de direcionamento, no caso, social, político e econômico, como representação de um projeto de Estado que fracassou no atendimento a seus cidadãos.

O galo no poema se define como "fato inusitado" em um bairro elegante. Nesse espaço, ele é visto de forma preconceituosa, o que justifica a proximação sonora entre os vocábulos "errante", "miliante" e "elegante". Pela afirmação de que a presença do galo no bairro é incomum, avulta a denúncia social dos anseios de classes prestigiadas que buscam desvincular-se do cenário rural, na ânsia de assegurar o citadino sofisticado. Todavia, nesse processo, há um esvaziamento existencial, pois prevalecem no cenário prestigiado inúmeros indivíduos estranhos a ele, provenientes do turismo, bem como a criminalidade, promovida pela má distribuição de renda. Essa ausência de relações equânimes é visível na geografia, que distingue Ipanema, como lugar prestigiado, filiado à modernidade, do morro desprestigiado, em que prevalecem traços do meio rural, como a criação de galos. Colasanti subverte assim o papel do "galo", de João Cabral, que em comunhão com outros inaugura a manhã.

Em seu texto, a escritora (2012) apresenta a simbiose insólita entre as figuras galo/calçada de Ipanema. Esse efeito de sentido (ISER, 1996 e 1999) advém da proximidade de espaços antagônicos e, assim, novamente, revela-se a alienação sujeito/espaço. Mesmo com seu canto aprisionado, o galo é majestoso e, apesar de permanecer em silêncio, sua presença comunica a discrepância social no Rio de Janeiro. Desse modo, o galo do poema de Colasanti 
(2012, p.23) afasta-se também daquele do poema de Gullar (JORNAL DE POESIA, 2020), pois não se configura como um arauto do alvorecer com seu grito solitário, rouco, sufocado, excluído. Ele comunica, consegue dar "seu recado": "sou do morro/ali ao lado" (2012, p.23). Nesse espaço intertextual, "o sentido poético remete a outros sentidos discursivos, de modo a serem legíveis no enunciado poético, outros discursos" (KRISTEVA, 1974, p.167). Prevalece o viés parodístico na criação de Colasanti (2012), pois o galo, mesmo sufocado, cumpre seu papel de denúncia de realidades opressivas. Justifica-se que, na ilustração de um galo, que dialoga com esse poema (2012, p.23), o animal apareça em movimento, altivo e com o olhar direcionado ao leitor, convocando-o à reflexão.

Para Linda Hutcheon (1991), o uso da paródia avulta como recurso por excelência dessa literatura, cuja natureza discursiva exige distância crítica. Segundo a estudiosa (1991), uma das contradições da produção pós-moderna é justamente a de que ela diminui o hiato entre formas artísticas altas e baixas, e o faz por meio da ironia em relação a ambas. Em sua produção, a poeta (2012) evita o distanciamento de seu leitor juvenil, aproximando-o das questões socioeconômicas do país, das violências por meio de uma linguagem direta, sem perder de vista o tom de perplexidade diante dos fatos, de inquietação, de inconformismo, mas também dos textos da tradição, pelo reconhecimento da dialogia.

O tema da fome e da alimentação permeiam os poemas e o título da terceira parte: "Os dentes e a fome" (2012, p.27-31). Um exemplo pode ser visto no poema a seguir:

\section{Um deleite esse leite}

O leite de vaca

não nasce em caixinha.

Sai puro da teta

completo e com nata.

Perfeita,

a embalagem de origem

fornece o produto direto do duto,

a ser aprovado

sem erro

na boca macia do bezerro. (2012, p.29)
No poema, o lúdico avulta no título paronômico (deleite/leite) e no emprego do nonsense, pelo recurso à potência de negação - "não nasce em caixinha" (2012, p.29). Essa estratégia assume viés crítico, pois problematiza para o jovem urbano a sociedade contemporânea que modifica até mesmo a criação mais "perfeita", a qual, pelo recurso da rima externa, provém da "teta": o "leite de vaca". Na oposição entre esse alimento natural, orgânico, e sua versão industrializada instaura-se a ironia. Este efeito de sentido resulta do recurso à reificação. Assim, parte do corpo da vaca - a "teta" -, é definida como "embalagem de origem", por sua vez, por meio desta obtém-se o leite, "produto", que chega ao destino certo - "sem erro" - ao sair "direto do duto" para a "boca macia do bezerro".

A potência de negação no poema também acentua 0 efeito de humor, pois alerta para 0 desconhecimento do jovem urbano da origem dos alimentos que consome, inclusive de sua composição. Pode-se observar que o eu lírico, ao definir o leite autêntico, completo e puro, adota um ritmo rápido, vibrante que, pelo recurso à sinestesia, aproxima o jovem de elementos gustativos e visuais, por ele ainda desconhecidos, como a "nata", já que o leite de "caixinha", consumido por ele, não precisa ser fervido. No poema, pelo recurso aos vazios instaurados no texto e à potência de negação, relativizam-se sentidos e a ausência deles, muitas vezes, instaurados no contexto social, pautado pela industrialização, que deturpa os alimentos, visando a ampliar sua durabilidade e assegurar ganho de capital.

A crítica à industrialização, que interfere na composição de um alimento o qual originalmente não pertence ao ser humano, realiza-se, ainda, pelo recurso à rima externa, na aproximação dos vocábulos "vaca" e "nata"; "teta" e "perfeita"; além da expressão "sem erro" e "bezerro". Desse modo, enfatiza-se que, na atualidade, o leite original só o bezerro conhece, pois ele o obtém diretamente da fonte. Pelo recurso à rima interna, reificação, metonímia e ironia, aproximase "produto" - leite de vaca - de "duto" - "teta" -, na definição do caminho que o leite percorre até a boca do bezerro. As expressões próprias da 
industrialização, utilizadas pelo eu lírico na definição de leite de vaca, denunciam a alienação do jovem urbano em seu conhecimento de mundo. Nesse sentido, a ilustração de uma vaca de costas que volta sua cabeça à direita com olhar distante, a qual dialoga com esse poema (2012, p.29), reforça a ideia de distanciamento entre esse animal e o leitor implícito, contemporâneo.

$\mathrm{Na}$ quarta parte, intitulada "O outro e o mesmo" (2012, p.35-40), denuncia-se pelos poemas a ilusão de se classificar de forma definitiva alguém ou algo. O poema, a seguir, expressa essa intenção:

\section{No rumo do sal}

O rio,
que nem criança,
corre corre
não se cansa
pula pedra
passa ponte
vai no plano
desce o monte
e para enfeitar caminho
se enrosca em rodamoinho.
Tanto entusiasmo
não é de espantar,
essa água doce
é como se fosse
a infância do mar. (2012, p.36)

Nota-se no poema que, visando à objetivação na primeira estrofe, o eu lírico é oculto, abrindo espaço para o objeto - rio -, tratado com relativa autonomia e distância. Desse modo, pelo recurso à comparação "O rio,/que nem criança," -, descreve-se em um ritmo bastante marcado e veloz suas ações, pautadas pela liberdade: "corre corre/não se cansa/pula pedra/passa ponte/vai no plano/desce o monte" (2012, p.36 destaques nossos). A aproximação com o poema "Trem de ferro", de Manuel Bandeira (ESCRITAS.ORG, 2020(2)), é inevitável e advém do recurso à velocidade, assegurada pela brevidade dos versos e pelo enjabement; à musicalidade; e ao ritmo - provenientes da rima externa, da aliteração em "p", da marcação binária e da anáfora na ação de correr. Todavia, na aproximação entre ambos poemas, notase que o alumbramento do eu lírico de Colasanti difere daquele do eu lírico de Bandeira, pois se direciona, pelo viés parodístico, a um elemento natural: o rio.
Esse rio, que "desce o monte", possui uma meta, busca o rumo do sal, metonímia de mar. Nesse processo, suas performances são descritas em versos breves, evocando o caminho que percorre velozmente entre margens estreitas. Somente, pela liberdade manifesta na arte - "enfeitar caminho" -, o rio amplia os espaços que o contém, realizando-se em "redemoinho". Como tributária do Concretismo e Modernismo, a poeta utiliza-se da mancha tipográfica visando à obtenção de efeitos de sentido. Justamente, a noção de "infância do mar" revela o "alumbramento" do eu lírico diante das primeiras vivências de uma criança em sua incorporação do jogo e do lúdico em suas brincadeiras. $O$ ritmo perde a velocidade na segunda estrofe em que o eu lírico, pelo recurso à sinestesia e ao emprego de vazios, posiciona-se a respeito do "entusiasmo" do rio ainda ingênuo, composto por "água doce", justificando-o como sendo "a infância do mar". O mar, por ser como um adulto, já perdeu a doçura, definindo-se pelo "sal" que compõe suas águas.

Desse modo, pela aproximação entre "rio" e "mar", e pelo distanciamento entre ambos, o eu lírico convoca o jovem leitor a refletir sobre as oposições que constituem um sujeito, configurado tanto pelas suas características intrínsecas, quanto pelas que lhe são agregadas pelo outro - alteridade -, o que justifica a inclusão do poema na quarta parte da coletânea, denominada "O outro e o mesmo". A ilustração de uma pequena cascata de água doce, cujas águas caem no leito de um rio pontuado por pedras, que dialoga com esse poema (2012, p.36), assegura o dinamismo das águas manifesto no plano verbal. Ademais, amplia o conceito de constituição do próprio rio, indicando que também outras águas o adentram e compõem, antes que atinja a sua dissolução e incorporação no mar.

O título da quinta parte, "Inventar a própria história" (2012, p.43-48), evoca a reflexão metaliterária que pontua seus poemas. Esse recurso pode ser visto no poema a seguir:

\section{O que será este chá?}

Na beira da xícara fina a mosca se inclina e olha o chá 
não sabe se aquilo é piscina

se é lago

ou banheira de spa. (2012, p.47)

Nesse poema, a aparição indesejada de uma mosca em um provável café da tarde torna perceptível o desconforto do inseto, que se inclina, sem identificar o que vê no conteúdo de uma xícara. Seu título sonoro, dotado de rima interna ("será" e "chá"), indica o hibridismo de gêneros textuais, pois aproxima-se de um enigma que se endereça a um narratário, além de ser pautado pelo relato, como se pode observar na progressão das ações da mosca, que se realizam em uma espacialidade. Esse título instaura o efeito de humor, pelo recurso à ironia, pois pode-se observar em sua análise que seu enunciado, embora interrogativo, contém a própria resposta. Os versos, embora também entreguem a um suposto narratário que o conteúdo da xícara é chá, instauram um jogo com ele. Para tanto, tratam da estranheza do espaço - xícara - para uma mosca. Esse efeito de humor e de estranhamento é acentuado pela ilustração, a qual dialoga com o poema (2012, p.47), de uma mosca pousada na beira de uma xícara, cujo olhar se volta para o seu conteúdo, como que $o$ analisando.

Esse inseto, incapaz de identificar o que contém a louça, o que se confirma na progressão de suas ações e no emprego da conjunção integrante "se", que instaura a dúvida - potência de indeterminação -, passa a criar hipóteses. Assim, o efeito de humor acentua-se, pois 0 alcance da imaginação da mosca segue o das proporções de seu corpo. Para ela, a xícara de chá pode ser piscina, lago ou banheira de spa. A incompatibilidade entre as figuras representativas do espaço e do sujeito (xícara fina/mosca) acentua o distanciamento entre elas, pois a mosca se aventura na descoberta de uma realidade que a rejeita e da qual certamente será banida. Esse provável banimento não a impede, todavia, de conjecturar, ou seja, em consonância com o título dessa quinta parte da coletânea; de "inventar a própria história". Como se pode observar, o discurso do eu lírico, por meio de tratamento sensível e cômico, afinase às emoções do jovem em seus desejos de liberdade criadora e subversão da realidade mundana.
Justamente, na última parte do livro, intitulada "O futuro é sempre adiante" (2012, p.51-57), os poemas tratam da passagem do tempo, como no poema a seguir:

\section{Correria sem serventia}

\author{
Um homem corre que corre \\ leva a vida em desatino \\ quase morre \\ pra ganhar qualquer instante. \\ Que tempo ganho que nada \\ o futuro é sempre adiante \\ e o camarada \\ só chega à hora marcada \\ no relógio do destino. (2012, p.53)
}

Por meio de um título paronômico e disposto em versos com rima externa, sendo o segundo pautado pela potência de negação, deflagra-se para o jovem leitor que ninguém pode reter o tempo, evitar a transitoriedade da vida, por mais que "corra", se esforce. Esse desejo de "[...] ganhar qualquer instante" é "sem serventia", conforme o título do poema, pois "o futuro é sempre adiante" (2012, p.53 grifos nossos). Desse modo, é impossível acumular o tempo ou controlá-lo, por isso quem corre tanto "leva a vida em desatino" (2012, p.53). A respeito do tempo, há somente uma certeza para o homem; a de sua finitude. Todavia, a data do término de seu próprio tempo escapa-lhe, pois quem a determina é o imponderável, o "destino". Este vocábulo, embora se aproxime do termo "desatino", pelo recurso à rima externa no poema, opõe-se a ele, pela sua superioridade em relação ao ser humano, que o pratica. Dialoga com esse poema a ilustração metonímica de uma engrenagem interna de um relógio (2012, p.53). Essa ilustração conota que somente o destino é capaz de conhecer a "hora marcada" para o final da vida, pois ele detém a completude do processo existencial de forma coerente. Ao homem, assim como para o leitor, resta conhecer apenas uma parte do mecanismo, a qual reconhece pela movimentação. $O$ cessar definitivo desta é uma incógnita para ele.

Neste e nos demais poemas analisados, a poesia juvenil "incorpora bem outra lição modernista: a de que o lirismo mais profundo pode ser trabalhado através dos temas mais prosaicos e mais cotidianos" 
(LAJOLO; ZILBERMAN, 2004, p.152). O prosaico configura-se no poema "Correria sem serventia", pelo recurso em seus versos à oralidade, gíria, potência de negação e repetição: "Que tempo ganho que nada/[...]/e o camarada" (2012, p.53 - grifos nossos). No plano semântico, esses recursos promovem o efeito de sentido de uma conversa descontraída que o eu lírico entabula com o leitor, dando-Ihe conselhos. Colasanti (2012), ao apropriar-se das inovações intentadas pelo Modernismo, Concretismo e pela Literatura contemporânea, como a exploração semântica da mancha tipográfica no papel, o adensamento prosaico dos versos, a dialogia, a metalinguagem, entre outros recursos, renova e reinaugura um tempo novo, o qual se revitaliza a cada encontro com o leitor, anulando, pela realização artística, a morte: tempo da finitude. Vale destacar que os poemas da coletânea (COLASANTI, 2012), pela interação, dispõem-se ao jogo que acionam com o leitor. Essa relação entre os poemas da coletânea (COLASANTI, 2012) e o leitor, de acordo com Iser (1999, p.13), caracteriza-se pelo fato deste último estar diretamente envolvido e, ao mesmo tempo, ser transcendido por aquilo em que se envolve, por meio da leitura.

\section{Considerações finais}

Em sua coletânea O nome da manhã (2012), Colasanti (2012) expressa sua "voz", por meio de uma poesia sensível, crítica e libertária. Em seus poemas manifesta a busca do sentido da vida, da temporalidade que a emoldura, das ações cotidianas, dos gestos e momentos que a pontuam, mesmo quando aparentemente corriqueiros. Como exercício de resistência e subversão à ordem capitalista, seu eu lírico captura em seu discurso cada instante como único, retirando-o da velocidade que define a vida hodierna que a tudo atribui valor e/ou dilui. Seus poemas, pautados por vazios e potências de negação, suscitam reflexão crítica, por meio da revisão de hipóteses. Para tanto, evocam dados familiares com a finalidade de relativizá-los e/ou negá-los, ajustando o processo interativo na leitura. Por meio desse processo, o leitor sem perder de vista o que foi problematizado, modifica sua posição em relação ao conhecido ou determinado socialmente. Desse modo, os poemas suscitam do leitor que situe a si mesmo em relação ao texto, bem como atualize e modifique seu ponto de vista de uma perspectiva de apresentação para outra, desenvolvendo novas expectativas. Nesse processo, instaura-se a comunicabilidade que convoca o olhar de descoberta, o qual assegura o prazer intelectual na leitura (ISER, 1999).

Na coletânea de Colasanti (2012), que se apropria da tradição, mas também a subverte, as palavras se impregnam de um tempo "vivo", que a cada leitura é ativado pelo leitor. Seu livro rompe com a temporalidade estanque do capital para tratar de transformações, imbricações e mesmo de idiossincrasias entre passado e presente, entre antigo e moderno, por meio da Literatura e da ilustração. Seus poemas, ao romperem com os modos convencionais de percepção, convidam o jovem leitor a (re)ver o mundo ou fragmentos dele, como algo vivo e novo, manifesto na Arte, única forma de expressão capaz de renovar e capturar o lampejo de beleza. De fato, esse lampejo, capturado pelo viés poético, disposto em discurso crítico e libertário, pode arrebatar, alumbrar o jovem leitor e mantê-lo atento durante a leitura, como que desperto à vida por um canto de galo/poeta.

A presença da narratividade em seus poemas indica o projeto estético de Colasanti, que visa a produzir textos essencialmente dinâmicos e, justamente por isso, adequados à renovação. Justificase a eleição do galo - que anuncia "nas trevas da noite que morre os primeiros clarões do espírito que se levanta" (CHEVALIER; GHEERBRANT, 1999, p.4589), símbolo solar desse dinamismo que afasta a imobilidade mortal. Em síntese, Colasanti busca, em seu construto, exercer a liberdade criadora, capaz de renascimentos e revisões do mundo, de rupturas com silenciamentos de vozes diversas e cerceamentos imobilizantes. Por meio de sua criação, pelo viés parodístico, dialoga com a tradição, subverte divisões estanques entre gêneros textuais, revitaliza o emprego da língua, instaura a crítica e o humor, rompendo com 
conceitos prévios do jovem leitor sobre o texto poético, em especial, de autoria feminina.

\section{Referências}

ARMAZÉM DE TEXTO. Disponível em: $<$ https://armazemdetexto.blogspot.com/2019/02/poem a-da-circunstancia-mario-quintana.html>. Acesso em: 10 jan. 2020.

CHEVALIER, Jean; GHEERBRANT, Alain. Dicionário de símbolos: mitos, costumes, gestos, formas, figuras, cores, números. Colab. de André Barault et al., coord. Carlos Sussekind, trad. Vera da Costa e Silva et al. 14.ed. Rio de Janeiro: José Olympio, 1999.

BOURDIEU, Pierre. O poder simbólico. Trad. Fernando Tomaz. 7.ed. Rio de Janeiro: Bertrand Brasil, 2004.

BOURDIEU, Pierre. As regras da arte: gênese e estrutura do campo literário. Trad. Maria Lucia Machado. São Paulo: Companhia das Letras, 1996.

CAMARGO, Luís H. de. Poesia infantil e ilustração: estudo sobre Ou isto ou aquilo de Cecília Meireles. 214 p. Dissertação de Mestrado pela Universidade estadual de Campinas - UNICAMP, São Paulo, 1998. CECCANTINI, João L. C. T. (org.). Leitura e literatura infanto-juvenil: memória de Gramado. São Paulo: Cultura Acadêmica: Assis, SP: ANEP, 2004.

COLASANTI, Marina. O nome da manhã. Ilustr. Marina Colasanti, São Paulo: Global, 2012.

COLASANTI, Marina. Minha guerra alheia. Rio de Janeiro: Record, 2010.

DIETZEL, Vera Lúcia. Recepção literária na Alemanha: entre o diálogo cultural e algumas escritoras brasileiras contemporâneas. In: SANTOS, Luísa Cristina dos (org.). Literatura e mulher: das linhas às entrelinhas. Ponta Grossa: Editora UEPG, 2002.

ESCRITAS.ORG. Disponível em: <https://www.escritas.org/pt/t/11508/tecendo-amanha>. Acesso em: 20 fev. 2020.

ESCRITAS.ORG. Disponível em: <https://www.escritas.org/pt/t/4171/trem-de-ferro>. Acesso em: 20 fev. 2020(2).
HUTCHEON, Linda. Poética do pós-modernismo: história, teoria, ficção. Trad. Ricardo Cruz. Rio de Janeiro: Imago, 1991.

ISER, Wolfgang. $O$ ato da leitura: uma teoria do efeito estético. Trad. Johannes Kretschmer. São Paulo: Ed. 34, 1999.

ISER, Wolfgang. $O$ ato da leitura: uma teoria do efeito estético. Trad. Johannes Kretschmer. São Paulo: Ed. 34, 1996.

JAUSS, Hans Robert. A história da literatura como provocação à teoria literária. Trad. Sérgio Tellaroli. São Paulo: Ática, 1994.

JORNAL DE POESIA. Disponível em: $<$ http://www.jornaldepoesia.jor.br/gula01.html>.

Acesso em: 10 jan. 2020.

KRISTEVA, Julia. Introdução à semanálise. Trad. Lúcia Helena França. São Paulo: Perspectiva, 1974.

LAJOLO, Marisa; ZILBERMAN, Regina. Literatura infantil brasileira: histórias e histórias. São Paulo: Ática, 2004.

LAURETIS, Teresa de. A tecnologia do gênero. In: HOLLANDA, Heloísa Buarque de. Tendências e impasses: o feminismo como crítica da cultura. Rio de Janeiro: Rocco, 1994.

LEMINSKI, Estrela Ruiz Leminski. Poesia é não. 1.reimpr. São Paulo: Iluminuras, 2013.

LINDEN, Sophie Van der. Para ler o livro ilustrado. Trad. Dorothée de Bruchard. São Paulo: Cosac Naify, 2011.

MARINACOLASANTI.COM. Disponível em: $<$ https:/www.marinacolasanti.com/p/biografia.html>.

Acesso em: 10 jan. 2020.

NOTATERAPIA. Disponível em: <http://notaterapia.com.br/2020/01/21/marinacolasanti-e-cica-fittipaldi-sao-indicadas-ao-premiohans-christian-andersen/>. Acesso em: 12 fev. 2020. OLIVEIRA, Rui de. Breve histórico da ilustração no livro infantil e juvenil. In: OLIVEIRA, leda de (org.). $O$ que é qualidade em ilustração no livro infantil e juvenil: com a palavra o ilustrador. São Paulo: DCL, 2008, p. 13-47.

SHOWALTER, Elaine. A crítica feminista no território selvagem. In: HOLLANDA, Heloísa Buarque de. 
Tendências e impasses: o feminismo como crítica da cultura. Rio de Janeiro: Rocco, 1994, p.23-57.

STALLONI, Yves. Os gêneros literários. Trad. e notas

Flávia Nascimento. Rio de Janeiro: Difel, 2001.

\section{COMO CITAR ESSE ARTIGO}

FERREIRA, Eliane Aparecida Galvao Ribeiro; BULHÕES, Ricardo Magalhães. Liberdade e denúncia social no texto poético de autoria feminina: Análise da obra O nome da manhã, de Marina Colasanti. Signo, Santa Cruz do Sul, v. 45, n. 83, p. 49-60, set. 2020. ISSN 1982-2014. Disponível em:

<https://online.unisc.br/seer/index.php/signo/article/view/14863>. Acesso em: doi:https://doi.org/10.17058/signo.v45i83.14863. 